\title{
A Conversation
}

\section{with Le Moyne W. Anderson}

Editor's Note: When Le Moyne W. Anderson, president of $A C R L$, came to Chicago in October for a meeting of the ACRL Executive Board, I was able to talk with him about his recent trip to China and about his career.

Anderson is director of libraries at Colorado State University, Fort Collins. He began his term of office as president of ACRL at the Annual Conference in June. In October he completed a year as president of ARL. Thus, for a period of several months during 1979 he had the unique distinction of being president of ACRL and ARL at the same time.

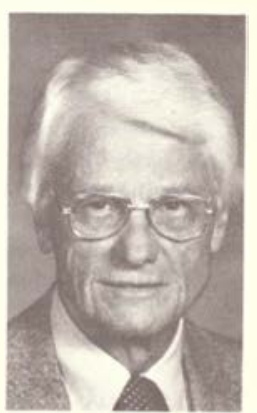

Le Moyne Anderson
Ed.: May I ask you about your career? How did you start out in the library profession?

LA: I came back from the experience of World War II, as did many young soldiers, with a serious outlook and a desire to get on with a career, but librarianship was something I hadn't thought of. A counselor guided me toward library science at the University of Minnesota, and two of the luminaries at the library school there, Donald Strout and Errett McDiarmid, were very kind to me and stimulated my interest in the profession.

When I got out of library school, my first objective was to work with an outstanding librarian. Charles Harvey Brown was at Iowa State then. I went down to Iowa State as serials librarian to work with him. That was my first job.

Ed.: What experiences were the best preparation for the administrative post you hold now?

LA: The best preparation was the grounding I received in the fundamentals by working in the trenches at lowa State and later at the University of Illinois at Chicago. I gained a foundation in technical services at Iowa State and then in public services at Illinois. I think that the journeyman experience of working in various positions is most important. I don't know how library schools can prepare you for an administrative position.

Ed.: Did you have a mentor?

LA: I had several of them and they were very important to me: I have mentioned the influence of Strout and McDiarmid at library school and
Brown at Iowa. I also had the opportunity to work at Illinois when Bob Downs was there. They were very important influences. They were persons who excelled. Then when I got on the job in 1957 as library director at Colorado State (I think I may have the record for longevity as a library director), Ralph Ellsworth, who was library director at the University of Colorado, was a great help to me and an important influence. Colorado State was then an "emerging institution." It was my job to develop the library program. We have had some success, but it was a long process that culminated, in a sense, when we were finally admitted to ARL.

Ed.: You earned a Ph.D. while you were a library director.

LA: I was kind of young when I went to Colorado State as library director. I used my first sabbatical to fulfill the course requirements for the $\mathrm{Ph}$. $\mathrm{D}$. at the University of Illinois, and I wrote my disser-

\section{Now Representing the Book House}

\author{
ARCHIE McNEAL former director \\ of libraries of the University of Miami. \\ He can show you why more and \\ more academic libraries depend on the \\ Book House for fast, efficient acquisi- \\ tion services.
}

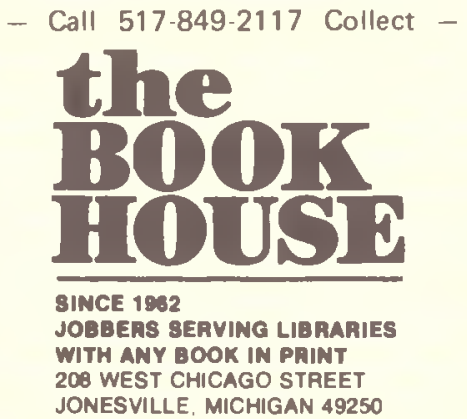


tation back on the job, working every Friday and Saturday for two years.

The push to go for the Ph.D. was largely selfinflicted. I had the feeling that I hadn't completed the whole experience of higher education, and now I'm glad I did. I have a feel now for what research is all about, can identify with the faculty I work with, and have been able to encourage my staff to do a lot of things in the library on the basis of research.

Ed.: Before letting you go, may I ask you about the American Library Delegation Study Trip to the Peoples Republic of China in September? You went on the trip as a representative of $A R L$. What are your impressions?

LA: We visited fourteen Chinese universities in five cities. Our hosts at each stop were so friendly; they wanted us to see everything. Invariably the first point that they made during the briefings was that the cultural revolution had been devastating to them. They are very much aware that China has fallen behind, and they agree that China must open its doors to the world and learn from it. They are serious about this. They want to learn about library practices in the West, especially in the area of automation.

It took us a while to realize how basic their needs are-where they are starting from. After a while we didn't assume anything. They know that learning Western methods is not enough; they need the technology that lies behind itcomputer hardware, and so on. Moreover, they have an especially difficult problem, since the task of converting Chinese characters to machine-readable form is defying the whole world. We kept telling them that China could make a special contribution in this area.

One of the purposes of the trip was to establish a communication link between librarians of the two countries. The next step in the process will come when our Chinese counterparts visit the nations of the Western world to see what we are doing.

\section{Academic/Research Librarian of the Year Award}

The Association of College and Research Libraries invites nominations for the Academic/ Research Librarian of the Year Award, presented jointly by ACRL and the Baker \& Taylor Company. Anyone wishing to submit nominations should request a nomination form from the ACRL office, 50 E. Huron St., Chicago, IL 60611.

Keyes D. Metcalf and Robert B. Downs shared the first Academic/Research Librarian of the Year Award in 1978. Henriette D. Avram and Frederick G. Kilgour were named corecipients of the second Academic/Research Librarian of the Year Award in 1979.

The Awards Committee selects persons to receive the award in accordance with the following guidelines:

Punpose: To recognize an individual member of the library profession who has made an outstanding national or international contribution to academic and research librarianship and library development.

Criteria: Persons nominated should have demonstrated achievements in such areas as:

1. Service to the organized profession through ACRL and related organizations.

2. Significant and influential research on academic or research library service.

3. Publication of a body of scholarly and/or theoretical writing contributing to academic or research library development.

4. Planning and implementing a library program of such exemplary quality that it has served as a model for others.

5. Nominee does not have to meet all four criteria stated above.

RuLES: The award shall be made each year at a time and place to be determined by the ACRL Board of Directors. Announcement of the award shall be made by the ACRL president at a time and place to be determined by the ACRL Board of Directors. If, in the opinion of the Award Committee, no worthy candidate is nominated in a given year, the award will not be made that year.

Nominations: Nominations for the award must be returned to the chairperson of the Academic/ Research Librarian of the Year Award Committee and must be postmarked no later than April 1, 1980. Nominations must be submitted in quintuplicate. Nominations must be complete on the application form. The presence of attachments will disqualify the nomination. Secondary letters will not be considered in the Award Committee's deliberations.

Nature of the Award: The Academic/ Research Librarian of the Year Award shall consist of $\$ 2,000$ and an appropriate citation. 